
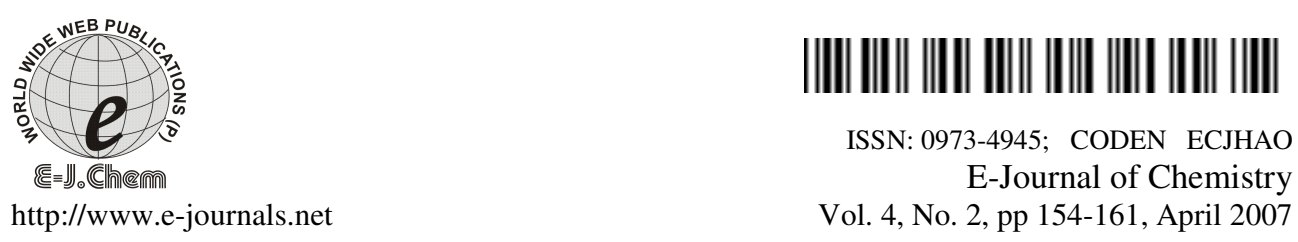

\title{
Sensitive Spectrophotometric Methods for the Determination of Gatifloxacin in Pharmaceuticals Using Bromate-Bromide, Methylene Blue and Rhodamine-B as Reagents
}

\author{
K. BASAVAIAH* and U. R. ANIL KUMAR \\ Department of Chemistry, \\ University of Mysore, \\ Manasagangotri, Mysore 570 006, India.
}

Received 6 October 2006; Revised 5 November 2006; Accepted 10 December 2006

\begin{abstract}
Two new simple, precise, rapid and extraction-free spectrophotometric methods are proposed for the determination of gatifloxacin(GTF) using bromate-bromide mixture and two dyes, methylene blue and rhodamine B, as reagents. Spectrophotometric methods entail the addition of a known excess of bromate-bromide mixture to GTF in hydrochloric acid medium followed by determination of residual bromine by reacting with a fixed amount of either methylene blue and measuring the absorbance at $665 \mathrm{~nm}$ (Method A) or rhodamine B and measuring the absorbance at $555 \mathrm{~nm}$ (Method B). Beer's law is obeyed in the ranges, 0.5-5.0 and $0.2-1.5 \mu \mathrm{g} \mathrm{mL}^{-1}$ for method $\mathrm{A}$ and method $\mathrm{B}$, respectively. The apparent molar absorptivities are calculated to be $5.6 \times 10^{4}$ and $9.6 \times 10^{4} \mathrm{~L} \mathrm{~mol}^{-1} \mathrm{~cm}^{-1}$ for method A and method B, respectively, and the corresponding Sandell sensitivity values are 0.0071 and $0.0042 \mu \mathrm{g} \mathrm{cm}^{-2}$. The methods were successfully applied to the assay of GTF in pharmaceutical formulations with satisfactory results.
\end{abstract}

Keywords: Gatifloxacin, assay, spectrophotometry, bromate-bromide, tablets.

\section{Introduction}

Gatifloxacin(GTF) is a synthetically derived,broad spectrum fluoroquinolone designed for both oral and intravenous administration. Chemically, it is ( \pm )-1-cyclopropyl-6-fluoro-1,4dihydro-8-methoxy-7-(3-methyl-1-piperazinyl)-4-oxo-3-quinoline carboxylic acid sesqui hydrate ${ }^{1}$ (Fig.1). It is indicated for acute pyelonephritis, acute bacterial exacerbation of chronic bronchitis and complicated UTI. 


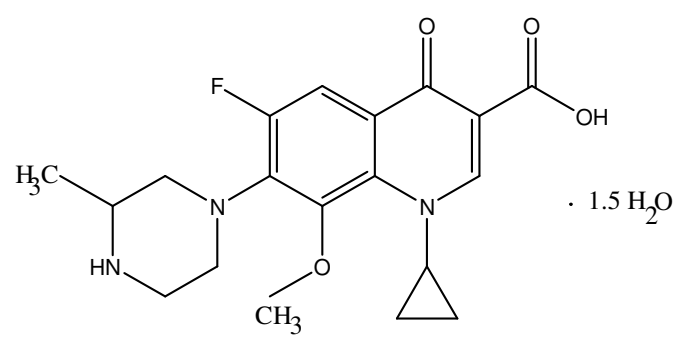

Figure 1. Structure of gatifloxacin sesqui hydrate

Various techniques have been used for the determination of GTF in body fluids and pharmaceuticals. High performance liquid chromatography (HPLC) has been applied for the determination of the drug in plasma ${ }^{2,3}$, serum $^{4}$, and serum and urine ${ }^{5}$. The drug in urine and serum has also been quantitated by spectrofluorimetry ${ }^{6}$. There is only one report on the application of HPLC for the assay of GTF in bulk and dosage forms. A non-aqueous titration procedure $^{7}$ has recently been described for the assay of drug in pharmaceutical formulations using perchloric acid as titrant. Very recently, Salgado et al. ${ }^{8}$ have reported a microbiological assay for GTF in pharmaceutical formulations. Several UVspectrophotometric ${ }^{9-13}$ procedures employing different media have also been reported for assay in single as well as combined dosage forms.

Visible spectrophotometry, because of simplicity and cost effectiveness, sensitivity and selectivity, and fair accuracy and precision has remained competitive in an era chromatographic techniques for pharmaceutical analysis. Many visible spectrophotometric methods based on different reaction schemes are found in the literature for the assay of GTF. In a method reported by Dhachinamoorthy et al. ${ }^{14}$ ferric ferricyanide was reduced by GTF and the blue chromogen formed was measured forming the basis of assay. A yellow-orange chromogen formed when GTF was treated with cerium(IV) was used by Devala and Babu ${ }^{15}$ for the determination of drug in $40-160 \mu \mathrm{g} \mathrm{mL}^{-1}$ range in dosage forms. Two methods, one based on redox-complexation reactions involving chromium (VI) and symdiphenylcarbazide and the other on Mannich reaction, have recently been reported by Saraswathi et al. ${ }^{16}$ There are two reports ${ }^{17,18}$ on the use of N-bromosuccinimide(NBS) as an oxidimetric reagent for the estimation of GTF. The methods are based on the determination of unreacted NBS with celestine blue or by charge transfer reaction involving metol and sulphanilamide. A similar method but using chloramine-T and gallocyanine ${ }^{18}$ as reagents is also found in the article. Three sensitive methods ${ }^{19}$ based on chloroform extractable ionassociation complexes formed by GTF with wool fast blue BL, Tropaeolineooo or bromophenol blue are also found in the literature. The reported visible spectrophotometric methods, although a couple of them sensitive, suffer from one or the other disadvantage such as use of an unstable reagent ${ }^{17,18}$, poor sensitivity ${ }^{14-16}$ or liquid-liquid extraction step ${ }^{16,19}$.

The present investigation aims to develop sensitive and cost-effective methods for the determination of GTF in pure form and in dosage forms using visible spectrophotometry. The methods utilize bromate-bromide mixture as oxidimetric/brominating reagent, which has successfully been used for the sensitive spectrophotometric determination of many bioactive substances ${ }^{20-28}$. The proposed methods have the advantages of speed and simplicity besides being accurate and precise, and can be adopted by the pharmaceutical laboratories for industrial quality control. 


\section{Experimental}

\section{Reagents and materials}

All chemicals used were of analytical reagent grade and distilled water was used to prepare all solutions. A stock standard solution equivalent to $1000 \mu \mathrm{gmL}^{-1} \mathrm{KBrO}_{3}$ containing a large excess of $\mathrm{KBr}$ was prepared by dissolving accurately weighed $100 \mathrm{mg}$ of $\mathrm{KBrO}_{3}$ (Sarabhai M. chemicals, Baroda, India) and $1.0 \mathrm{~g}$ of $\mathrm{KBr}$ ( S.d. Fine Chem. Ltd., Mumbai, India) in water and diluting to $100 \mathrm{~mL}$ in a volumetric flask. The above solution was diluted appropriately with water to get 25 and $10 \mu \mathrm{g} \mathrm{mL}^{-1}$ in $\mathrm{KBrO}_{3}$ concentrations for method A and method B, respectively. To prepare $40 \mu \mathrm{g} \mathrm{mL}^{-1}$ methylene blue for method A, first, a $400 \mu \mathrm{g} \mathrm{mL}^{-1}$ dye solution was prepared by dissolving $57 \mathrm{mg}$ of dye (Qualigen fine-chem., Mumbai, assay $70 \%$ ) in water and diluting to $100 \mathrm{~mL}$ in a calibrated flask, and filtered using glass wool. This was appropriately diluted to get the required concentration. For method B, first, a $500 \mu \mathrm{g} \mathrm{mL} \mathrm{mL}^{-1}$ rhodamine B solution was prepared by dissolving $62.5 \mathrm{mg}$ of dye (s.d.fine-chem Ltd., Mumbai, $80 \%$ assay) in water and diluting to $100 \mathrm{~mL}$, and filtered. This was appropriately diluted with water to get $50 \mu \mathrm{g} \mathrm{mL}^{-1}$. Hydrochloric acid (5M) was prepared by diluting $43 \mathrm{~mL}$ of concentrated acid (s.d.fine-chem Ltd., Mumbai, Sp gr 1.18) to $100 \mathrm{~mL}$ with water. Pharmaceutical grade GTF, certified to be $99.85 \%$ pure was procured from Cipla India Ltd, Mumbai, India, and was used as received. A $500 \mu \mathrm{g} \mathrm{mL}^{-1}$ stock solution of GTF was prepared by dissolving accurately weighed $50 \mathrm{mg}$ of pure drug in water with the aid of heat and diluted to $100 \mathrm{~mL}$ with water in a calibrated flask. This was diluted with water to get working concentrations of 10 and $5 \mu \mathrm{g} \mathrm{mL} \mathrm{m}^{-1}$ GTF for method A and method B, respectively.

\section{Method using methylene blue (method A)}

Aliquots of pure GTF solution $\left(0.5\right.$ to $\left.5.0 \mathrm{~mL} ; 10 \mu \mathrm{g} \mathrm{mL} \mathrm{m}^{-1}\right)$ were accurately measured and transferred into a series of $10 \mathrm{~mL}$ calibrated flasks and the total volume was adjusted to $5.0 \mathrm{~mL}$ with water. To each flask were added $1 \mathrm{~mL}$ of $5 \mathrm{M}$ hydrochloric acid followed by $1 \mathrm{~mL}$ of bromate-bromide mixture $\left(25 \mu \mathrm{g} \mathrm{mL}^{-1}\right.$ in $\left.\mathrm{KBrO}_{3}\right)$. The flasks were closed, the content was mixed well and the flasks were set aside for 10 min with occasional shaking. Finally, $1 \mathrm{~mL}$ of $40 \mu \mathrm{g} \mathrm{mL}^{-1}$ methylene blue solution was added to each flask, diluted to the mark with water and the absorbance of solution was measured at $665 \mathrm{~nm}$ against reagent blank after $10 \mathrm{~min}$.

\section{Method using rhodamine B (method B)}

Varying aliquots $(0.5-3.0 \mathrm{~mL})$ of $5 \mu \mathrm{g} \mathrm{mL}^{-1} \mathrm{GTF}$ solution were measured accurately and delivered into a series of $10 \mathrm{~mL}$ calibrated flasks and the total volume was brought to $3.0 \mathrm{~mL}$ with water. To each flask were added $1 \mathrm{~mL}$ each of $5 \mathrm{M}$ hydrochloric acid and bromate-bromide mixture $\left(10 \mu \mathrm{g} \mathrm{mL}^{-1}\right.$ in $\left.\mathrm{KBrO}_{3}\right)$ successively; the flasks were closed and let stand for $10 \mathrm{~min}$ with occasional shaking. Then, $1 \mathrm{~mL}$ of $50 \mu \mathrm{g} \mathrm{mL}{ }^{-1}$ rhodamine B solution was added to each flask; the volume was adjusted to the mark with water and mixed well. The absorbance of each solution was measured at $555 \mathrm{~nm}$ against a reagent blank after $10 \mathrm{~min}$.

In either spectrophotometric method, the concentration of the unknown was read from the calibration graph or computed from the regression equation derived from the Beer's law data. 


\section{Assay procedure for formulations}

An amount of finely ground tablet powder equivalent to $50 \mathrm{mg}$ of GTF was accurately weighed into a beaker, $50 \mathrm{~mL}$ water was added and stirred for $20 \mathrm{~min}$ and warmed. Then, the content of the beaker was quantitatively transferred into a $100 \mathrm{~mL}$ calibrated flask, diluted to the mark with water and mixed well, and filtered using a Whatman No 42 filter paper. First $10 \mathrm{~mL}$ portion of the filtrate was discarded and a suitable aliquot of the subsequent portion $\left(500 \mu \mathrm{g} \mathrm{mL} L^{-1}\right.$ GTF) was diluted appropriately to get 10 and $5 \mu \mathrm{g} \mathrm{mL}^{-1}$ concentrations for analysis by method $\mathrm{A}$ and method $\mathrm{B}$, respectively.

\section{Results and Discussion}

The proposed spectrophotometric methods are indirect and are based on the determination of the residual bromine (insitu generated) after allowing the reaction between GTF and a measured amount of bromine to be complete. The surplus bromine was determined by reacting it with a fixed amount of either methylene blue or rhodamine -B dye. The methods rely on the bleaching action of bromine on the dyes, the decolouration being caused by the oxidative destruction of the dyes.

GTF when added in increasing amounts to a fixed amount of insitu generated bromine, consumes the latter proportionately and there occurs a concomitant fall in the amount of bromine. When a fixed amount of dye is added to decreasing amounts of bromine, a concomitant increase in the concentration of dye results. Consequently, a proportional increase in the absorbance at the respective $\lambda_{\max }$ is observed with increasing concentration of GTF (Figs.2 and 3).

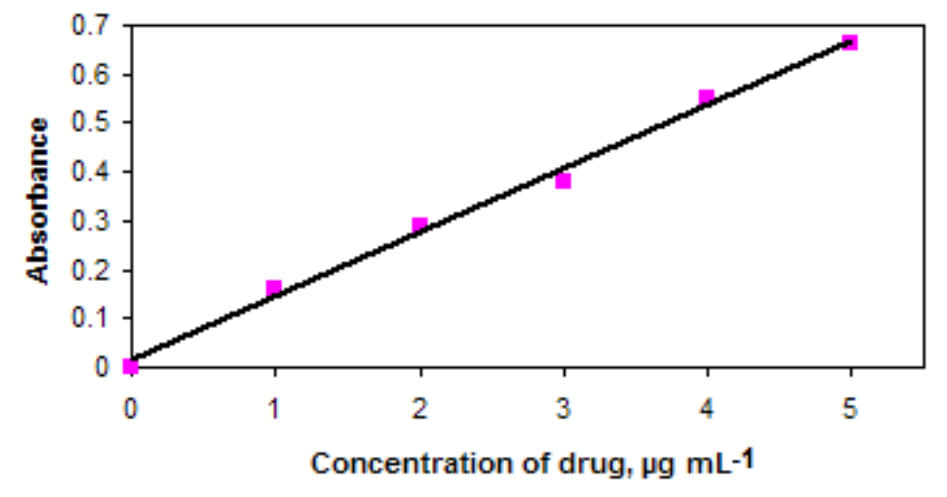

Figure 2. Beer's law curve for method A

Preliminary experiments were performed to fix the upper limits of the dyes that could be determined spectrophotometrically, and these were found to be 4 and $5 \mu \mathrm{g} \mathrm{mL}^{-1}$ for methylene blue and rhodamine $\mathrm{B}$, respectively. A bromate concentration of $2.5 \mu \mathrm{g} \mathrm{mL}^{-1}$ was found to irreversibly destroy the blue colour of $4 \mu \mathrm{g} \mathrm{mL}^{-1}$ methylene blue whereas $1.0 \mu \mathrm{g}$ $\mathrm{mL}^{-1}$ bromate in the presence of a large excess of bromide was required to bleach red colour due to $5 \mu \mathrm{g} \mathrm{mL}^{-1}$ rhodamine B. Hence, different amounts of GTF were reacted with $1 \mathrm{~mL}$ of $25 \mu \mathrm{g} \mathrm{mL}{ }^{-1}$ bromate in method $\mathrm{A}$ and $1 \mathrm{~mL}$ of $10 \mu \mathrm{g} \mathrm{mL}^{-1}$ bromate in method B followed by determination of the residual bromine as described under the respective procedures. 


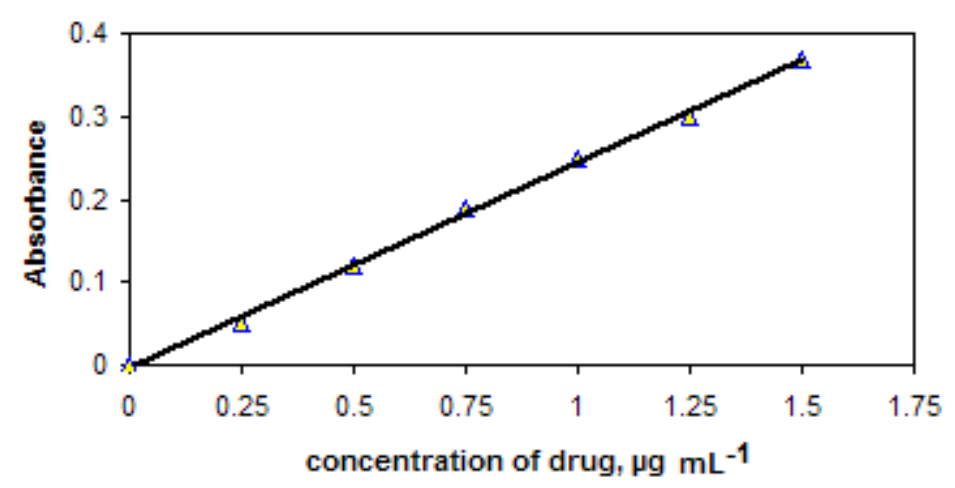

Figure 3. Beer's law curve for method B

For both steps, i.e., bromination of drug and bleaching of dye by bromine, hydrochloric acid medium was found to be ideal. One $\mathrm{mL}$ of $5 \mathrm{M}$ hydrochloric acid in a total volume of about $3-5 \mathrm{~mL}$ was adequate for the bromination step which was complete in $10 \mathrm{~min}$ in both methods and the same quantity of acid was employed for the estimation of the dye. Contact time of $10 \mathrm{~min}$ is not critical and any delay upto $30 \mathrm{~min}$, had no effect on the absorbance in both methods.

\section{Analytical data}

A linear correlation was found between absorbance at $\lambda_{\max }$ and concentration of GTF.

The graphs showed negligible intercept and are described by the equation:

$$
\mathrm{Y}=\mathrm{a}+\mathrm{bX}
$$

(where $\mathrm{Y}=$ absorbance of $1-\mathrm{cm}$ layer of solution; $\mathrm{a}=$ intercept; $\mathrm{b}=$ slope and $\mathrm{X}=$ concentration in $\mu \mathrm{g} \mathrm{mL}^{-1}$ ). Regression analysis of the Beer's law data using the method of least squares was made to evaluate the slope (b), intercept (a) and correlation coefficient(r) for each system and the values are presented in Table 1. The optical characteristics such as Beer's law limits, molar absorptivity and Sandell sensitivity values of both methods are also given in Table 1. The limits of detection (LOD) and quantitation(LOQ) calculated according to ICH guidelines ${ }^{29}$ are also presented in Table. 1 and reveal the very high sensitivity of the spectrophotometric methods.

\section{Method Validation}

\section{Accuracy and precision}

To evaluate the accuracy and precision of the methods, pure drug solution at three different levels (within the working limits) was analysed, each determination being repeated seven times. The relative error (\%) and relative standard deviation (\%) were less than 2.0 and indicate the high accuracy and precision for the methods (Table 2). For a better picture of reproducibility on a day-to-day basis, a series of experiments were performed in which standard drug solution at three different levels was determined each day for five days with all solutions being prepared afresh each day. The day-to-day relative standard deviation values were in the range of $2.5-3.5 \%$ and represent the best appraisal of the methods in routine use. 
Table 1. Analytical and regression parameters of the proposed methods

\begin{tabular}{|c|c|c|}
\hline Parameter & Method A & Method B \\
\hline$\lambda_{\max }, \mathrm{nm}$ & 665 & 555 \\
\hline Beer's law limits, $\left(\mu \mathrm{g} \mathrm{mL}^{-1}\right)$ & $0.5-5.0$ & $0.2-1.5$ \\
\hline Molar absorptivity, $\left(\mathrm{L} \mathrm{mol}^{-1} \mathrm{~cm}^{-1}\right)$ & $5.6 \times 10^{4}$ & $9.6 \times 10^{4}$ \\
\hline Sandell sensitivity, $\left(\mu \mathrm{g} \mathrm{cm}^{-2}\right)$ & 0.0071 & 0.0042 \\
\hline Limit of detection, $\left(\mu \mathrm{g} \mathrm{mL}^{-1}\right)$ & 0.07 & 0.05 \\
\hline Limit of quantification, $\left(\mu \mathrm{g} \mathrm{mL}^{-1}\right)$ & 0.21 & 0.16 \\
\hline \multicolumn{3}{|l|}{ Regression equation, $\mathrm{Y}^{*}$} \\
\hline Intercept (a) & 0.0300 & -0.0067 \\
\hline Slope (b) & 0.1260 & 0.2514 \\
\hline Correlation coefficient, (r) & 0.9965 & 0.9986 \\
\hline $\mathrm{S}_{\mathrm{a}}$ & 0.0193 & 0.0069 \\
\hline $\mathrm{S}_{\mathrm{b}}$ & 0.0061 & 0.0066 \\
\hline
\end{tabular}

Table 2. Evaluation of accuracy and precision

\begin{tabular}{ccccccccc}
\hline Method & $\begin{array}{c}\text { GTF } \\
\text { taken, } \\
\left(\mu \mathrm{mL}^{-1}\right)\end{array}$ & $\begin{array}{c}\text { GTF } \\
\text { Found }^{*}, \\
\left(\mu \mathrm{g} \mathrm{mL}^{-1}\right)\end{array}$ & $\begin{array}{c}\text { Range, } \\
\left(\mu \mathrm{g} \mathrm{mL}^{-1}\right)\end{array}$ & $\begin{array}{c}\text { RE } \\
(\%)\end{array}$ & $\begin{array}{c}\text { SD, } \\
(\mu \mathrm{g} \\
\left.\mathrm{mL}^{-1}\right)\end{array}$ & $\begin{array}{c}\text { SEM, } \\
(\mu \mathrm{g} \\
\left.\mathrm{mL}^{-1}\right)\end{array}$ & $\begin{array}{c}\text { RSD, } \\
(\%)\end{array}$ & $\begin{array}{c}\text { ROE, ** } \\
(\%)\end{array}$ \\
\hline Method & 1.5 & 1.48 & 0.01 & 1.59 & 0.022 & 0.008 & 1.46 & \pm 1.46 \\
A & 2.5 & 2.47 & 0.04 & 1.17 & 0.029 & 0.011 & 1.18 & \pm 1.18 \\
& 3.5 & 3.46 & 0.19 & 1.25 & 0.063 & 0.024 & 1.82 & \pm 1.82 \\
Method & 0.5 & 0.49 & 0.01 & 1.21 & 0.004 & 0.002 & 0.84 & \pm 0.84 \\
B & 1.0 & 0.99 & 0.02 & 1.09 & 0.008 & 0.003 & 0.83 & \pm 0.83 \\
& 1.5 & 1.48 & 0.06 & 1.10 & 0.019 & 0.007 & 1.31 & \pm 1.31 \\
\hline
\end{tabular}

RE. relative error; SD. Standard deviation; SEM. Standard error of mean; RSD. Relative standard deviation; ROE. Range of error;

* Mean value of seven determinations

** At the $95 \%$ confidence level for 6 degrees of freedom.

\section{Application to analysis of commercial samples}

In order to check the validity of the proposed methods, GTF was determined in some commercial formulations. Table 3 gives the results of the determination from which it is clear that there is close agreement between the results obtained by the proposed methods and the label claim. The results were also compared statistically by the Student's t- test for accuracy and the variance ratio F- test for precision with those of the reference $\operatorname{method}^{9}$ at $95 \%$ confidence level. The calculated t- and F-values (Table 3 ) did not exceed the tabulated values $(\mathrm{t}=2.77, \mathrm{~F}=6.39)$ except in a couple of instances for four degrees of freedom indicate that there was no significant difference between the proposed methods and the reference method in respect to accuracy and precision.

The accuracy and validity of the proposed methods were further ascertained by performing recovery studies. Pre-analysed tablet powder was spiked with pure GTF at three different levels and the total was found by the proposed methods. Each determination was repeated three times. The recovery of the pure drug added was 
quantitative and revealed that co-formulated substances such as talc, starch, gelatin, gum acacia, calcium carbonate, calcium gluconate, calcium dihydrogen orthophosphate, sodium alginate and magnesium stearate did not interfere in the determination. The results of recovery study are compiled in Table-4.

Table 3. Results of determination of gatifloxacin in formulations and statistical comparison with the reference method

\begin{tabular}{|c|c|c|c|c|}
\hline \multirow[b]{2}{*}{$\begin{array}{l}\text { Tablet brand } \\
\text { name }^{\#}\end{array}$} & \multirow{2}{*}{$\begin{array}{c}\text { Nominal } \\
\text { amount, } \\
(\mathrm{mg})\end{array}$} & \multicolumn{3}{|c|}{$\%$ Found $* \pm$ SD } \\
\hline & & $\begin{array}{c}\text { Reference } \\
\text { method }\end{array}$ & $\begin{array}{c}\text { Method } \\
\text { A }\end{array}$ & $\begin{array}{c}\text { Method } \\
\text { B }\end{array}$ \\
\hline GAITY $^{\mathrm{a}}$ & 400 & $100.6 \pm 0.55$ & $\begin{array}{l}99.8 \pm 1.05 \\
t=1.58 \\
F=3.64\end{array}$ & $\begin{array}{l}101.1 \pm 1.03 \\
t=1.00 \\
F=3.51\end{array}$ \\
\hline GATIQUIN $^{\mathrm{b}}$ & 200 & $99.8 \pm 0.81$ & $\begin{array}{l}98.5 \pm 1.01 \\
t=2.26 \\
F=1.55\end{array}$ & $\begin{array}{l}101 \pm 1.02 \\
t=2.07 \\
F=1.59\end{array}$ \\
\hline G-CEBRAN ${ }^{\mathrm{c}}$ & 400 & $101.6 \pm 0.65$ & $\begin{array}{l}99.95 \pm 1.02 \\
t=3.12 \\
F=2.46\end{array}$ & $\begin{array}{l}101.9 \pm 1.33 \\
t=0.48 \\
F=4.19\end{array}$ \\
\hline
\end{tabular}

*Mean value of five determinations

\#Marketed by: a. Reddy's Ltd.; b. Cipla Ltd.; c. Blue cross Ltd.

Tabulated t-value at $95 \%$ confidence level is 2.77

Tabulated F-value at 95\% confidence level is 6.39 .

Table 4. Results of recovery experiments by standard addition method

\begin{tabular}{lcccccccc}
\hline & \multicolumn{3}{c}{ Method A } & \multicolumn{5}{c}{ Method B } \\
\cline { 2 - 9 } $\begin{array}{c}\text { Tablets } \\
\text { studied }\end{array}$ & $\begin{array}{c}\text { Amount Amount } \\
\text { of drug of pure } \\
\text { in } \\
\text { tablet } \\
(\mu \mathrm{g})\end{array}$ & $\begin{array}{c}\text { Total } \\
\text { added, } \\
(\mu \mathrm{g})\end{array}$ & $\begin{array}{c}\text { found } \\
(\mu \mathrm{g})\end{array}$ & $\begin{array}{c}\text { Pure drug } \\
\text { recovered* } \\
(\%)\end{array}$ & $\begin{array}{c}\text { Amount } \\
\text { of drug } \\
\text { in tablet } \\
(\mu \mathrm{g})\end{array}$ & $\begin{array}{c}\text { Amount } \\
\text { of pure } \\
\text { drug } \\
\text { added } \\
(\mu \mathrm{g})\end{array}$ & $\begin{array}{c}\text { Total } \\
\text { found } \\
(\mu \mathrm{g})\end{array}$ & $\begin{array}{c}\text { Pure drug } \\
\text { recovered* } \\
(\%)\end{array}$ \\
\hline \multirow{5}{*}{ GAITY } & 19.96 & 10 & 30.08 & 101.2 & 5.06 & 2.5 & 7.62 & 102.3 \\
& 19.96 & 20 & 40.46 & 102.5 & 5.06 & 5.0 & 10.05 & 99.8 \\
& 19.96 & 30 & 50.23 & 100.9 & 5.06 & 7.5 & 12.58 & 100.3 \\
G-CEBRAN & 20 & 10 & 29.97 & 99.7 & 5.1 & 2.5 & 7.68 & 103.2 \\
& 20 & 20 & 39.66 & 98.3 & 5.1 & 5.0 & 10.01 & 98.2 \\
& 20 & 30 & 50.18 & 100.6 & 5.1 & 7.5 & 12.64 & 100.5 \\
\hline
\end{tabular}

*Mean value of three determinations

\section{Conclusions}

Two useful micro methods for the determination of GTF have been developed and validated as per the ICH guidelines. The methods are simple and rapid taking not more than 15-20 min for the assay. Both spectrophotometric methods are more sensitive than the existing UV and HPLC methods, and are free from such experimental variables as heating or extraction step. The methods rely on the use of simple and cheap chemicals and techniques but provide a sensitivity comparable to that achieved by sophisticated and expensive technique like HPLC. 
Both methods employ a solution which is quite stable in solution unlike many reported visible spectrophotometric procedures where the oxidimetric reagents require daily standardization. Compared to reported spectrophotometric methods (both UV and visible) the present methods are highly sensitive and in fact, method $B\left(\varepsilon=9.6 \times 10^{4} \mathrm{~L} \mathrm{~mol}^{-1} \mathrm{~cm}^{-1}\right)$ is the most sensitive ever reported for gatifloxacin. Thus, they can be used as alternatives for rapid and routine determination of bulk sample and tablets.

\section{References}

1. Douglas N Pharmacotherapy. 2001, 21, 35.

2. Hairui L, Michael B K and Kelvin M S, J.Chromatogr.B Anal. Technol.Biomed. Life Sci. 2002, 772, 53.

3. Saleh Al-Dgither, Syed Naseeruddin Alvi and Muhammad M H, J. Pharm. Biomed. Anal. 2006, 41, 251.

4. Hoang A N, Jean G, Boubakar B B, Claudine Q, and Marie-Claude S, J. Chromatogr. B. 2004, 810, 77 .

5. Brian R O, Michael B K and Kelvin M S, J. Chromatogr.B. Anal. Technol . Biomed.Life Sci . 2003, 798, 167.

6. Juan A O, Francisco J B and Manuel C, J. Pharm. Biomed. Anal. 2005, 37, 327.

7. Marona Herida R N, Lopes Cristiani C G O and Cardoso Simone G, Acta Farmaceutica Bonaerense. 2003, 22, 339.

8. Salgado H R N, Lopes C C G O and Lucchesi M B B, J.Pharm. Biomed .Anal. 2006, 40, 443.

9. Venugopal K and Ranendra N S, IL Farmaco. 2005, 60, 906.

10. Patel P U, Suhagia B N, Patel C N, Patel M M, Patel Gayatri C and Patel Geeta M, Indian J Pharm. Sci. 2005, 67, 356.

11. Wang Xiao-Ling, Li Dong and Nie Zhong-Yue, Yaохие Fuwu Yи Yanjiu. 2005, 5, 57.

12. Salgado H R N and Oliveira C L C G, Pharmazie. 2005, 60, 263.

13. Xu Q, Qin X and Deng L, Guangdong Yaoxueyuan Xuebao. 2003, 19, 234.

14. Dhachinamoorthi D, Dash S, Mariappan G and Sangeetha K, Pharma Review. 2004, 2, 120.

15. Devala G and Babu I S, Indian pharmacist. 2004, 3, 78.

16. Thangavel N, Raman S, Angalaparameswari S and Beena K P, International J. Chemical Sci. 2005, 3, 263.

17. Prasad Siva K V, Prabhakar G, Rao S V M M, Kumar K S and Haritha G, Acta Ciencia Indica. 2003, 29, 163.

18. Rao K V S P, Srinivasulu C, Nagaraju P, Sagineedu S R and Prabhakar G, Oriental J. Chemistry. 2003, 19, 583.

19. Prasad K V S, Prabhakar G, Rao S V M M, Sandhya M and Jagganath G, Asian J. Chemistry. 2003, 15, 1170.

20. Basavaiah K and Prameela H C, Science Asia, 2003, 29, 147.

21. Basavaiah K and Prameela H C, Anal.Bioanal.Chem. 2003, 376, 879.

22. Basavaiah K and Chandrashekar U, Acta Ciencia Indica Chem. 2003, 29, 25.

23. Basavaiah K and Nagegowda P, ILFarmaco. 2004, 59, 147.

24. Basavaiah K and Nagegowda P, Oxid.Commun. 2004, 27, 203.

25. Basavaiah K and Prameela H C, Indian J.Pharm.Sci.2004, 67, 883.

26. Basavaiah K,. Indian J.Chem. Technol. 2005, 149, 12.

27. Basavaiah K and Nagegowda P, J.Braz.Chem.Soc. 2005,16, 821.

28. Basavaiah K and Somashekar B C, Indian J.Chem.Technol. 2006,12, 316.

29. Validation of Analytical Procedures; Methodology, International Conference on Harmonization (ICH) 1994, 6. 


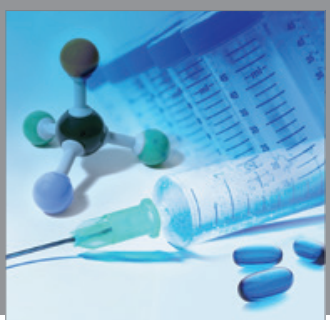

International Journal of

Medicinal Chemistry

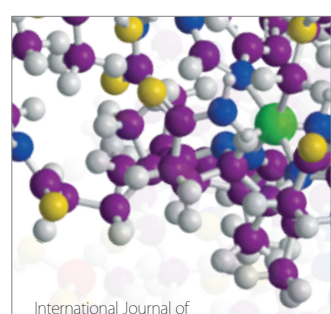

Carbohydrate Chemistry

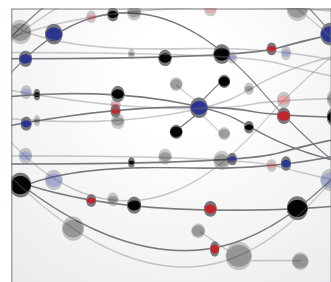

The Scientific World Journal
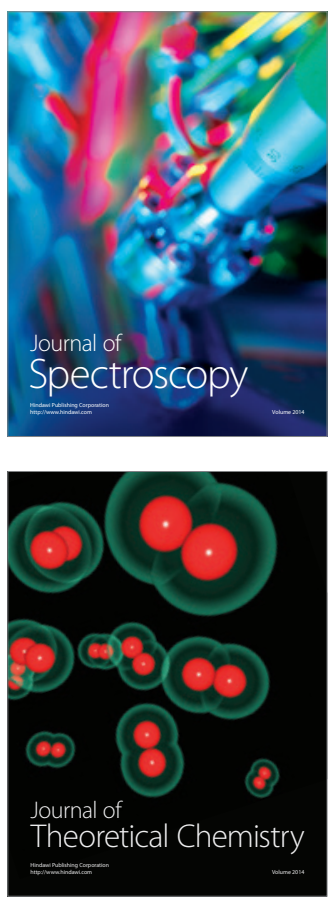
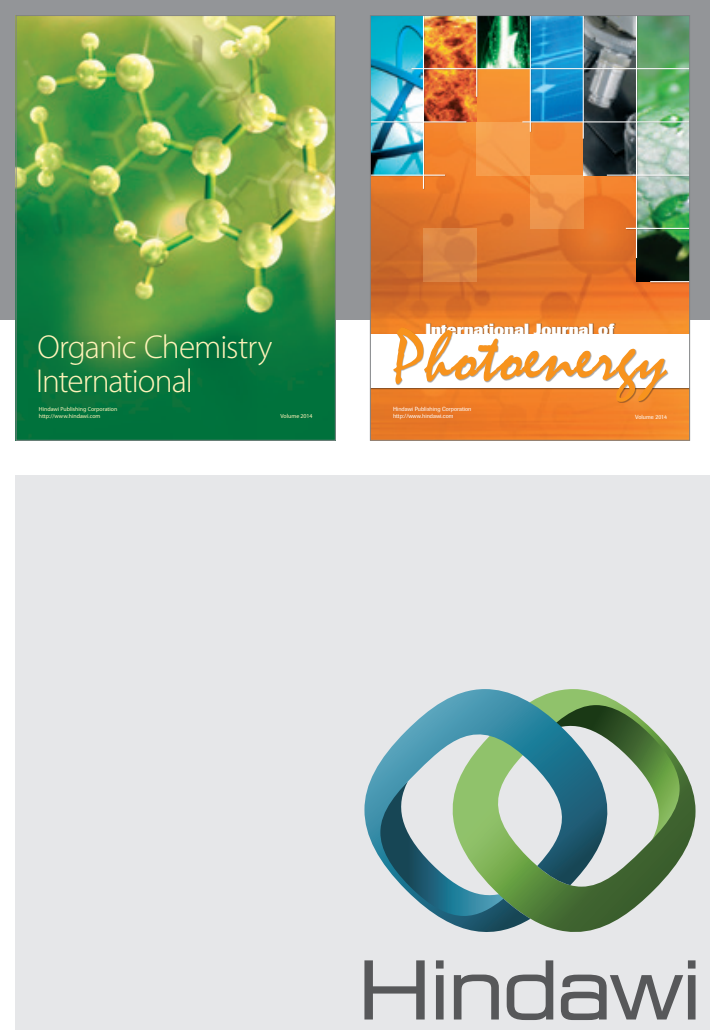

Submit your manuscripts at

http://www.hindawi.com
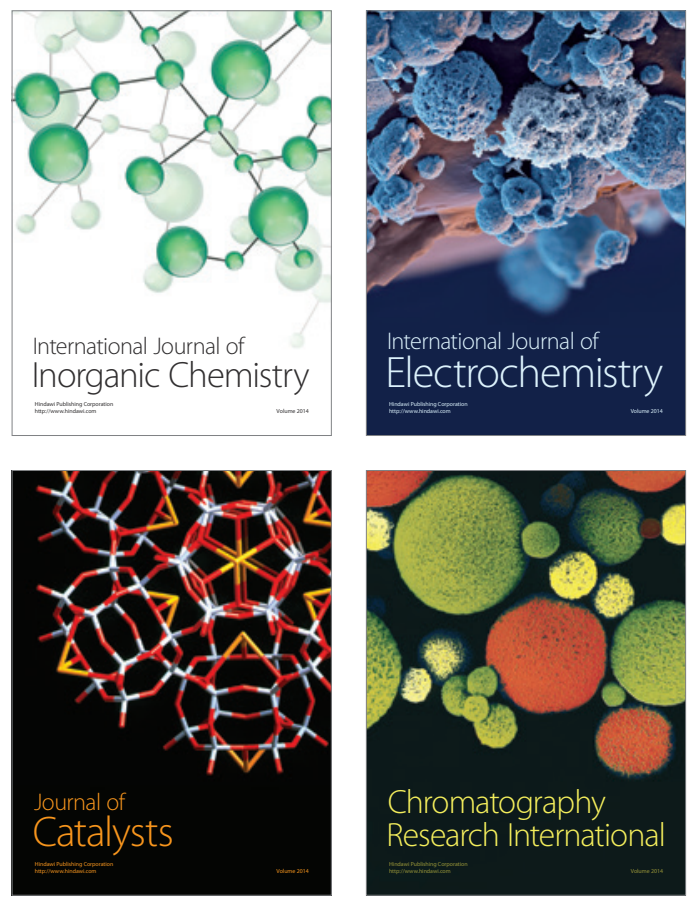
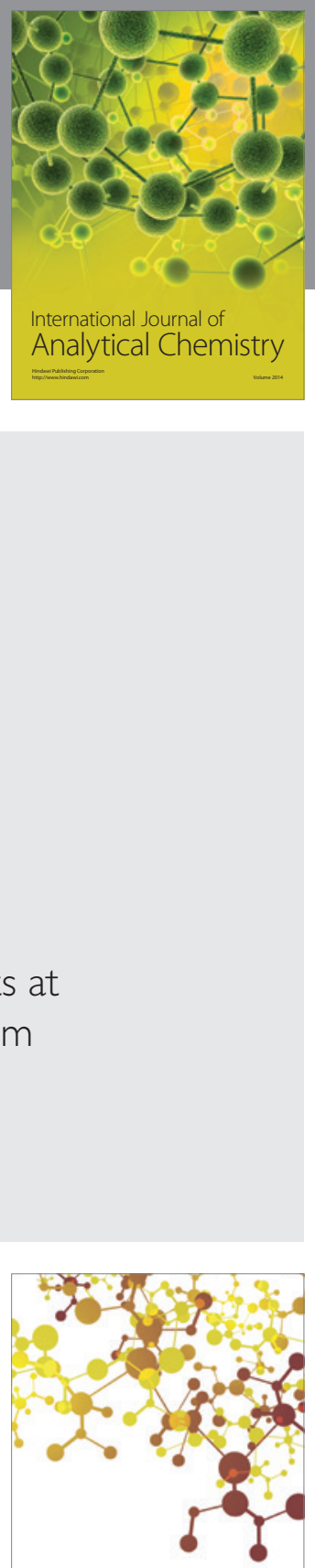

Journal of

Applied Chemistry
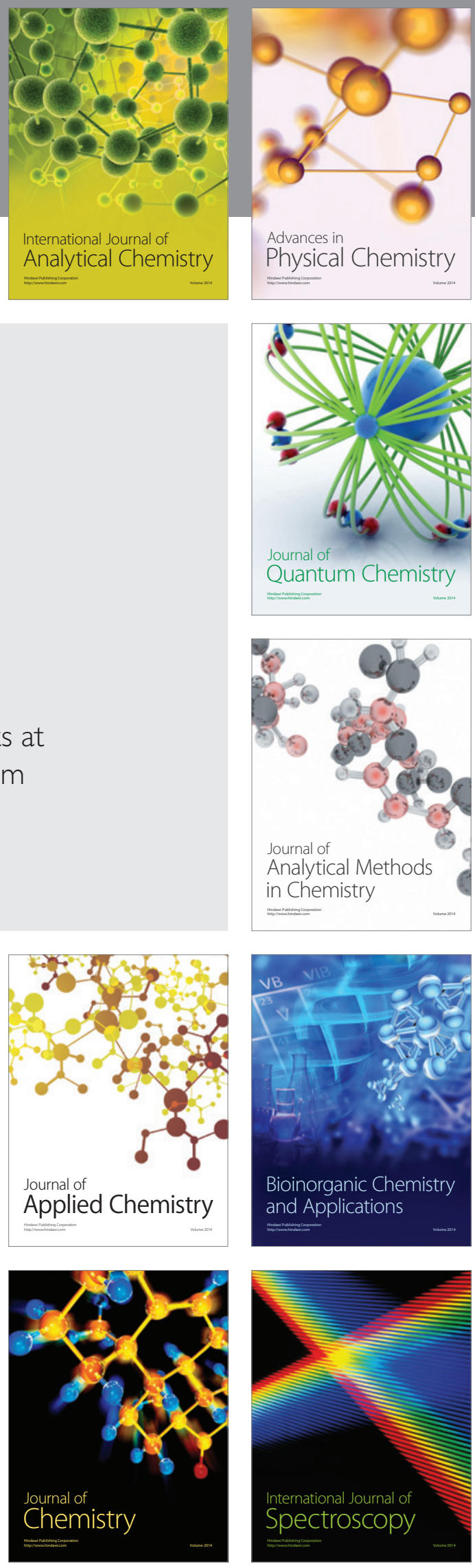